\title{
Pemanfaatan Bubuk Rimpang Laja Gowah (Alpinia malaccensis Rosc.) pada Pengawetan Ikan Gabus (Channa striata) Segar Selama Penyimpanan pada Suhu Kamar
}

\section{Utilization of Rhizome Laja Gowah Powder (Alpinia malaccensis Rosc) in Preserving Fish (Channa striata) Fresh During Storage at Room Temperature}

\author{
Dewi Merdekawati ${ }^{1}$, M Zakiyul Fikri ${ }^{2}$ \\ ${ }^{1}$ Dosen Faperta UNIDA \\ ${ }^{2}$ Dosen Politeknik Tanjungbalai
}

Email: dewhi.08@gmail.com

\begin{abstract}
A study was conducted in June 2009 at the Laboratory of Fish Technology Products, Food Microbiology and Food Chemistry Faculty of Fisheries and Marine Science University of Riau. The purpose was to obtain the proper ratio of the powdered rhizome for Laja Gowah cork fresh fish preservation at room temperature, and to know the effect of rhizome powder concentration of laja gowah organoleptic value, the value of TVB, the TPC and the pH value of cork fish (Channa striata) fresh. The design used was Random Design Group (RAK) non-factorial. The treatment given were rhizome powder with a concentration laja gowah $\mathrm{L}_{0}$ (laja gowah 0\%), $\mathrm{L}_{1}$ (laja gowah $5 \%$ ), $\mathrm{L}_{2}$ (laja gowah 10\%) and $\mathrm{L}_{3}$ (laja gowah $15 \%$ ). While the group is the long storage $0,1,3$, and 5 days. $\mathrm{L}_{3}$ treatment with 5 -day storage time showed the value of TPC $=2.24 \times 10^{5}$, the value $\mathrm{mgN} / 100 \mathrm{TVB}=36 \mathrm{~g}, \mathrm{pH}=7.12$, the highest organoleptic value of meat texture value (3.24), followed by the value of smell (3.00), the value of sight appearance (3.00), the value of mucus condition (2.88) and gill appearance value (2.24). From the results of research obtained that the concentration of $15 \%$ powder rhizome laja gowah was the best for preservation of fresh fish with a long cork storage for 5 days.
\end{abstract}

Keywords : Channa striata, storage, powdered rhizome laja gowah.

\begin{abstract}
ABSTRAK
Penelitian dilakukan pada bulan Juni 2009 di Laboratorium Teknologi Hasil Perikanan, Mikrobiologi Pangan, dan Kimia Pangan Fakultas Perikanan dan Ilmu Kelautan Universitas Riau. Tujuannya adalah untuk mendapatkan rasio yang tepat dari bubuk rimpang laja gowah untuk pengawetan ikan gabus segar pada suhu kamar, dan untuk mengetahui pengaruhnya terhadap nilai organoleptik, nilai TVB, TPC dan nilai $\mathrm{pH}$. Rancangan percobaan yang digunakan adalah Rancangan Acak Kelompok (RAK) non-faktorial. Perlakuan yang diberikan adalah konsentrasi bubuk rimpang laja gowah dengan $\mathrm{L}_{0}$ (laja gowah 0\%), $\mathrm{L}_{1}$ (laja gowah $5 \%$ ), $\mathrm{L}_{2}$ (laja gowah $10 \%$ ) dan $\mathrm{L}_{3}$ (laja gowah 15\%). Sedangkan kelompok adalah lama penyimpanan yaitu $0,1,3$, dan 5 hari. Perlakuan $\mathrm{L}_{3}$ dengan waktu penyimpanan 5 hari menunjukkan nilai TPC $=2,24 \times 10^{5}$, nilai mgN / $100 \mathrm{TVB}=36 \mathrm{~g}, \mathrm{pH}=7,12$ serta nilai organoleptik tertinggi dari nilai tekstur daging $(3,24)$, diikuti oleh nilai bau $(3,00)$, nilai kenampakan mata (3.00), nilai keadaan lendir $(2,88)$ dan nilai kenampakan insang $(2,24)$. Hasil penelitian diperoleh bahwa konsentrasi bubuk laja gowah $\mathrm{L}_{3}$ $(15 \%)$ adalah yang terbaik untuk pengawetan ikan gabus segar dengan lama penyimpanan 5 hari.
\end{abstract}

Kata Kunci : Ikan gabus, masa simpan, bubuk rimpang laja gowah

Dewi Merdekawati dan M. Zakiyul Fikri. 2017. Pemanfaatan Bubuk Rimpang Laja Gowah (Alpinia malaccensis Rosc.) pada Pengawetan Ikan Gabus (Channa striata) Segar Selama Penyimpanan pada Suhu Kamar. Jurnal Mina Sains 3(2): 50-57. 


\section{PENDAHULUAN}

Ikan gabus (Channa striata) merupakan salah satu jenis ikan air tawar yang terdapat diberbagai perairan umum seperti rawa-rawa, danau, dan kolam. Produksi ikan gabus di daerah Riau masih mengandalkan usaha penangkapan di perairan umum. Pada tahun 2004 produksi ikan gabus segar di Provinsi Riau sebesar 765 ton per tahun sedangkan pada tahun 2007 produksi ikan gabus segar sebesar 930,9 ton per tahun (Dinas Perikanan Daerah Tingkat I Provinsi Riau, 2008).

Ikan adalah bahan pangan yang mudah rusak (highly perishable). Menurunnya mutu ikan terus berlanjut apabila tidak dihambat. Hal ini dipengaruhi oleh beberapa faktor yaitu faktor dari sifat ikan, lingkungan, dan perlakuan manusia. Ada dua cara utama untuk menghambatnya seperti pengeringan, pemanasan, pemasakan, penggaraman, dan pendinginan (Singgih 1998).

Cara yang paling banyak digunakan di Indonesia adalah dengan metode penggunaan suhu rendah, baik dengan metode teknik refrigerasi ataupun dengan penggunaan es. Namun dalam penerapan metode ini masih banyak ditemukan kendala yang dihadapi oleh para nelayan diantaranya yaitu sulitnya para nelayan dalam menyediakan es bila jumlah hasil tangkapan cukup banyak dan harga es semakin mahal. Sehingga nelayan memilih alternatif lain yaitu dengan menggunakan zatzat kimia seperti boraks dan formalin yang dapat membahayakan kesahatan bagi konsumen. Alternatif lain sebagai bahan pengawet yang sifatnya alami, mudah didapat dan bersifat tidak membahayakan kesehatan, sangat diharapkan untuk dapat mempertahankan mutu ikan tersebut.

Laja gowah (Alpinia malaccensis Rosc), selain mengandung komponen antibakteri yang dapat digunakan sebagai pengawet alami juga ketersediaannya melimpah dan harganya murah. Dilatarbelakangi hal tersebut diatas dan belum diketahuinya pengaruh penggunaan bubuk laja gowah terhadap mutu ikan air tawar maka dilakukan penelitian tentang penggunaan bubuk laja gowah terhadap mutu ikan gabus segar selama penyimpanan suhu kamar. Tujuan penelitian ini adalah untuk mendapatkan rasio yang tepat dari bubuk rimpang gaja lowah untuk pengawetan ikan gabus segar pada suhu kamar, nilai TVB, nilai TPC, $\mathrm{pH}$ dan nilai organoleptik ikan gabus segar.

\section{BAHAN DAN METODE}

\section{Waktu dan Tempat}

Penelitian dilaksanakan pada bulan Juni 2009 yang bertempat di Laboratorium Teknologi Hasil Perikanan, Laboratorium Mikrobiologi Pangan, Kimia Pangan Fakultas Perikanan dan Ilmu Kelautan Universitas Riau.

\section{Bahan dan Alat}

Ikan yang dipakai adalah ikan gabus (Channa striata) sebanyak 32 ekor dengan berat rata-rata 300 - 500 gram/ekor, rimpang laja gowah (Alpinia malaccensis Rosc.). Laja gowah yang digunakan sebanyak 2000 gram dari berat total ikan yang digunakan. Bubuk kering didapatkan dengan proses pengeringan menggunakan panas matahari selama \pm 3 hari (kadar air $8-10 \%$ ). Rimpang yang telah kering dihaluskan dengan blender hingga menjadi bubuk halus. Bubuk disimpan dalam wadah dan disimpan dalam lemari pendingin.

\section{Rancangan Penelitian}

Rancangan yang digunakan dalam penelitian ini adalah Rancangan Acak Kelompok (RAK) non faktorial dengan 4 perlakuan konsentrasi yang berbeda dan lama penyimpanan sebagai kelompok $(0,1,3$, dan 5 hari). Perlakuan tersebut, yaitu :

1) Laja gowah $0 \%$

2) Laja gowah $5 \%$

3) Laja gowah $10 \%$

4) Laja gowah $15 \%$

Model matematika yang digunakan menurut Gasperz (1994) adalah sebagai berikut:

Keterangan :

$$
\mathrm{Yij}=\mu+\tau \mathrm{i}+\beta \mathrm{j}+\varepsilon \mathrm{ij}
$$

Yij = variable yang diukur

$\mu=$ nilai tengah umum

$\tau \mathrm{i}=$ pengaruh perlakuan

$\beta \mathrm{j}=$ pengaruh kelompok ke- $\mathrm{j}$

$\varepsilon \mathrm{ij}=$ pengaruh galat percobaan dari perlakuan ke-i dan pada kelompok ke-j 


\section{Parameter Pengamatan Analisa TPC}

Uji TPC dilakukan dengan tujuan untuk menentukan jumlah bakteri yang terkandung sehingga dapat menentukan bahan pangan tersebut masih layak atau tidak untuk dikonsumsi. Pengujian ini dilakukan dengan cara sebagai berikut: pembuatan media agar NA sebanyak 18,75 gram dan ditambahkan $1000 \mathrm{ml}$ aquades kedalam erlenmeyer dan diaduk sampai homogen. Media dididihkan selama beberapa menit sampai terbentuk larutan bening dan kemudia disterilkan dalam autoklaf pada suhu $121{ }^{\circ} \mathrm{C}$ selama 15 menit beserta peralatan lainnya yang akan digunakan untuk uji TPC.

Pembuatan larutan pengencer menggunakan $\mathrm{NaCl} 9$ gram dan dilarutkan dalam 1 liter aquades dan diaduk sampai homogen kemudian disterilkan dalam autoklaf. Selanjutnya sampel sebanyak 1 gram dilarutkan dengan $9 \mathrm{ml}$ larutan pengencer $0,9 \%$ $\mathrm{NaCl}$ yang telah disterilkan dan homogeny sehingga terbentuk pengenceran $10^{-1}$. Dari pengenceran tadi diambil sebanyak $1 \mathrm{ml}$ dan campurkan dengan $9 \mathrm{ml}$ larutan pengencer sehingga terbentuk pengenceran $10^{-2}$. Prosedur yang sama dilakukan berulang-ulang sampai diperoleh pengenceran $10^{-3}, 10^{-4}$, dan $10^{-5}$.

Campurkan media dan sampel ke dalam cawan petri, biarkan selama 15-20 menit sampai membeku kemudian diinkubasi selama 24 jam pada suhu $37{ }^{\circ} \mathrm{C}$ dengan posisi cawan terbalik. Kemudian perlakuan yang sama dilakukan pada pengenceran $10^{-3}, 10^{-4}$, dan $10^{-}$ ${ }^{5}$. Setelah masa inkubasi berakhir maka jumlah koloni pada masing-masing pengenceran dihitung, dimana perhitungan jumlah bakteri adalah jumlah koloni yang dihitung dikalikan dengan faktor pengencer.

$$
\text { Total bakteri }=\mathrm{N} \times \frac{1}{\text { faktor pengencer }}
$$

\section{Analisa TVB}

Uji TVB dilakukan dengan tujuan untuk menentukan mutu bahan pangan, kadarnya akan semakin meningkat seiring dengan semakin turunnya penurunan mutu bahan pangan tersebut. Pengujian ini dilakukan dengan cara sebagai berikut : Sampel ditimbang sebanyak 5 gram dan ditambahkan
$15 \mathrm{ml}$ larutan 7\% TCA. Campuran disaring sehingga diperoleh filtrate yang jernih. Dipipet sebanyak $1 \mathrm{ml}$ larutan asam boraks kemudian dimasukkan dalam inner chamber cawan conway. Hasil filtrate dipipet sebanyak $1 \mathrm{ml}$ kemudian dimasukkan dalam outer chamber cawan conway. Ditambahkan $1 \mathrm{ml}$ larutan $\mathrm{K}_{2} \mathrm{CO}_{3}$ jenuh ke outer chamber setelah itu cawan ditutup rapat dan diinkubasi pada suhu $35{ }^{\circ} \mathrm{C}$ selama 2 jam. Setelah selesai diinkubasi, larutan asam boraks dalam inner chamber dititrasi dengan larutan $\mathrm{N} / 70 \mathrm{HCl}$ sehingga warna larutan berubah warna menjadi merah muda. Perhitungan kadar TVB :

$$
\begin{aligned}
\text { Kadar TVB }-\mathrm{N} & =(\mathrm{X}-Y) \\
& \times 80 \mathrm{mg} \mathrm{N} \\
& / 100 \text { gram sampel }
\end{aligned}
$$

\section{Analisa pH}

Analisa $\mathrm{pH}$ dilakukan dengan menggunakan $\mathrm{pH}$ meter.

\section{Penilaian Organoleptik}

Penilaian organoleptik dilakukan oleh 25 orang panelis agak terlatih. Penilaian ini bertujuan untuk mengamati bau, kenampakan mata, kenampakan insang, keadaan lender, dan tekstur daging menggunakan score sheet organoleptik yang telah disediakan.

\section{HASIL DAN PEMBAHASAN}

\section{Nilai Total Koloni Bakteri (TPC)}

Hasil perhitungan terhadap nilai total koloni bakteri (TPC) ikan gabus yang diawetkan dengan bubuk laja gowah pada konsentrasi yang berbeda dipaparkan pada Tabel 1.

Berdasarkan Tabel 1 didapatkan nilai total bakteri yang paling tinggi adalah pada perlakuan $\mathrm{L}_{0}$ yaitu $8,92 \times 10^{5}$ dan terendah adalah perlakuan $\mathrm{L}_{3}$ yaitu $2,24 \times 10^{5}$. Batas maksimum jumlah mikroba dalam bentuk produk olahan bahan pangan untuk konsumsi manusia sebesar $5 \times 10^{5} \mathrm{sel} /$ gram (Dirjen POM 1992). Berdasarkan hasil penelitian dapat terlihat bahwa semakin tinggi konsentrasi bubuk rimpang laja gowah yang digunakan maka semakin rendah nilai total bakteri. Namun seiring dengan lamanya waktu penyimpanan maka total bakteri semakin meningkat disebabkan karena sifat antibakteri 
yang ada pada laja gowah tidak mampu lagi menghambat pertumbuhan mikroorganisme pembusuk. Pertumbuhan mikroorganisme pembusuk tersebut akan lebih aktif dengan adanya enzim-enzim yang menguraikan senyawa-senyawa protein yang dapat mempengaruhi pertumbuhan mikroorganisme. Selain itu pertumbuhan bakteri juga disebabkan oleh adanya kondisi lingkungan yang dapat mempengaruhi pertumbuhannya.

Tabel 1. Rata-rata nilai total koloni bakteri (TPC) ikan gabus yang diawetkan dengan bubuk laja gowah pada konsentrasi berbeda yang disimpan pada suhu kamar

\begin{tabular}{crrrr}
\hline \multirow{3}{*}{ Perlakuan } & \multicolumn{4}{c}{ Rata-rata TPC $($ sel/gram) } \\
\cline { 2 - 5 } & \multicolumn{4}{c}{ Lama penyimpanan (hari) } \\
\cline { 2 - 5 } & $10,8 \times 10^{4}$ & $26,4 \times 10^{4}$ & 3 & \multicolumn{1}{c}{5} \\
\hline $\mathrm{L}_{0}$ & $7,6 \times 10^{4}$ & $20,4 \times 10^{4}$ & $4,68 \times 10^{5}$ & $8,92 \times 10^{5}$ \\
$\mathrm{~L}_{1}$ & $6,8 \times 10^{4}$ & $13,6 \times 10^{4}$ & $1,56 \times 10^{5}$ & $6,32 \times 10^{5}$ \\
$\mathrm{~L}_{2}$ & $2,8 \times 10^{4}$ & $11,2 \times 10^{4}$ & $1,56 \times 10^{5}$ & $2,24 \times 10^{5}$ \\
$\mathrm{~L}_{3}$ &
\end{tabular}

Ket: $\mathrm{L}_{0}=0 \%, \mathrm{~L}_{1}=5 \%, \mathrm{~L}_{2}=10 \%, \mathrm{~L}_{3}=15 \%$

\section{Nilai Total Volatile Basa (TVB)}

Hasil penelitian terhadap nilai TVB dari ikan gabus yang diawetkan dengan bubuk laja gowah pada konsentrasi yang berbeda dapat dilihat pada Tabel 2.

Total volatile basa terbentuk sebagai hasil pembusukan yang disebabkan oleh aktivitas mikroba, proses autolisis dan oksidasi atau kombinasi dari aktivitas mikroba, autolisis dan oksidasi (Hadiwiyoto 1993). Dari data kenaikan TVB dilihat bahwa perlakuan $\mathrm{L}_{3}(36$ $\mathrm{mgN} / 100 \mathrm{~g}$ daging) dapat mempertahankan mutu ikan gabus selama 3 hari. Sesuai dengan pendapat Connel (1995) bahwa batas penolakan mutu hasil perikanan ditentukan oleh nilai TVB bila mencapai $35-40 \mathrm{mgN} / 100$ gram daging ikan.

Tabel 2. Rata-rata nilai TVB ikan gabus yang diawetkan dengan bubuk laja gowah pada konsentrasi berbeda yang disimpan pada suhu kamar

\begin{tabular}{|c|c|c|c|c|c|c|}
\hline \multirow{3}{*}{ Perlakuan } & \multicolumn{4}{|c|}{ Rata-rata TVB (mgN/100 gr) } & \multirow{3}{*}{ Total perlakuan } & \multirow{3}{*}{ Rata-rata } \\
\hline & \multicolumn{4}{|c|}{ Lama penyimpanan (hari) } & & \\
\hline & 0 & 1 & 3 & 5 & & \\
\hline $\mathrm{L}_{0}$ & 26 & 34 & 84 & 138 & 282 & 70,5 \\
\hline $\mathrm{L}_{1}$ & 22 & 26 & 56 & 80 & 184 & 46 \\
\hline $\mathrm{L}_{2}$ & 18 & 22 & 48 & 72 & 160 & 40 \\
\hline $\mathrm{L}_{3}$ & 16 & 20 & 36 & 68 & 140 & 35 \\
\hline Total kelompok & 82 & 102 & 224 & 358 & 766 & \\
\hline
\end{tabular}

Ket: $\mathrm{L}_{0}=0 \%, \mathrm{~L}_{1}=5 \%, \mathrm{~L}_{2}=10 \%, \mathrm{~L}_{3}=15 \%$

\section{Nilai pH}

Hasil penelitian terhadap nilai $\mathrm{pH}$ dari ikan gabus yang diawetkan dengan bubuk laja gowah pada konsentrasi yang berbeda dapat dilihat pada Tabel 3.

Tinggi rendahnya nilai $\mathrm{pH}$ ini erat kaitannya dengan tingkat pertumbuhan bakteri, dimana semakin rendah nilai $\mathrm{pH}$ maka semakin rendah pula kemampuan bakteri untuk melakukan pertumbuhan yang dapat menyebabkan rendahnya kadar volatile basa yang dihasilkan sebaliknya dengan tingginya nilai $\mathrm{pH}$ maka pertumbuhan bakteri yang berlangsung cepat sehingga akan meningkatkan kadar volatile basa.

Rata-rata nilai $\mathrm{pH}$ menunjukkan bahwa terjadinya peningkatan nilai $\mathrm{pH}$ selama penyimpanan untuk semua perlakuan, nilai $\mathrm{pH}$ tertinggi terdapat pada perlakuan Lo kemudian diikuti oleh $\mathrm{L}_{1}, \mathrm{~L}_{2}$, dan $\mathrm{L}_{3}$. Semakin tingginya konsentrasi bubuk rimpang laja gowah yang digunakan maka semakin rendah pula nilai $\mathrm{pH}$ yang dihasilkan. Perlakuan $\mathrm{L}_{0}$ hanya mampu bertahan selama 1 hari penyimpanan, perlakuan $\mathrm{L}_{1}$ dan $\mathrm{L}_{2}$ mampu bertahan selama 3 hari penyimpanan sedangkan perlakuan $\mathrm{L}_{3}$ mampu bertahan selama 5 hari penyimpanan. 
Buckle et al. (1987) menyatakan bahwa beberapa mikroorganisme dapat memecah senyawa sumber energi bagi kehidupan, biasanya senyawa organik seperti protein, lemak, gula dan senyawa anorganik yang secara alamiah ada dalam bahan pangan, hal tersebut dapat menyebabkan meningkatnya nilai pH. Ilyas (1993) menyatakan bahwa $\mathrm{pH}$ optimum untuk pertumbuhan bakteri adalah 77,5. Pendapat ini didukung oleh Hadiwiyoto (1993) yang menyatakan bahwa kebanyakan bakteri lebih sukar hidup pada keadaan netral sampai sedikit basa ( $\mathrm{pH}>7)$. Pada keadaan asam pertumbuhan bakteri terhambat, namun beberapa jenis bakteri masih bisa hidup pada keadaan asam.

Tabel 3. Rata-rata nilai $\mathrm{pH}$ ikan gabus yang diawetkan dengan bubuk laja gowah pada konsentrasi berbeda yang disimpan pada suhu kamar

\begin{tabular}{lllllll}
\hline \multirow{2}{*}{ Perlakuan } & \multicolumn{4}{c}{ Rata-rata nilai $\mathrm{pH}$} & & \\
\cline { 2 - 5 } & \multicolumn{4}{c}{ Lama penyimpanan (hari) } & Total perlakuan & Rata-rata \\
\cline { 2 - 5 } & 0 & 1 & 3 & 5 & & \\
\hline $\mathrm{L}_{0}$ & 6,73 & 7,11 & 8,02 & 8,63 & 30,49 & 7,62 \\
$\mathrm{~L}_{1}$ & 6,68 & 6,72 & 7,03 & 7,88 & 28,31 & 7,08 \\
$\mathrm{~L}_{2}$ & 6,54 & 6,61 & 6,98 & 7,73 & 27,86 & 6,97 \\
$\mathrm{~L}_{3}$ & 6,47 & 6,53 & 6,78 & 7,12 & 26,90 & 6,73 \\
\hline Total kelompok & 26,42 & 26,97 & 28,81 & 31,36 & 113,56 & \\
\hline
\end{tabular}

Ket: $\mathrm{L}_{0}=0 \%, \mathrm{~L}_{1}=5 \%, \mathrm{~L}_{2}=10 \%, \mathrm{~L}_{3}=15 \%$

\section{Nilai Organoleptik \\ Bau}

Berdasarkan hasil penelitian terhadap nilai organoleptic bau dari ikan gabus yang diawetkan dengan bubuk rimpang laja gowah pada konsentrasi yang berbeda dapat dilihat pada Tabel 4.

Nilai organoleptic bau ikan gabus mengalami penurunan seiring dengan lamanya penyimpanan. Nilai organoleptic bau tertinggi dimiliki oleh $\mathrm{L}_{3}$ sebesar 3,00 (tawar, netral) sedangkan nilai terendah dimiliki $\mathrm{L}_{0}$ yaitu 0,48 (bau busuk). Penurunan nilai bau selama penyimpanan disebabkan oleh penguraian sifat-sifat bahan makanan dan jenis mikroba yang tumbuh dominan. Winarno (1980) menyatakan bahwa pada bahan pangan yang menghasilkan enzim yang dapat menguraikan protein sehingga menghasilkan bau busuk. Bau busuk ini semakin nyata dengan berlanjutnya pembusukan. Oleh sebab itu semakin meningkat jumlah mikroorganisme yang terdapat pada bahan pangan maka semakin nyata perubahan bau yang terjadi akibat aktivitas enzim pengurai protein yang dihasilkan bakteri tersebut.

Tabel 4. Nilai organoleptic bau ikan gabus yang diawetkan dengan bubuk rimpang laja gowah pada konsentrasi yang berbeda disimpan pada suhu kamar

\begin{tabular}{lllllll}
\hline \multirow{2}{*}{ Perlakuan } & \multicolumn{4}{c}{ Nilai organoleptik } & & \\
\cline { 2 - 5 } & \multicolumn{4}{c}{ Lama penyimpanan (hari) } & & \\
\cline { 2 - 5 } & 0 & 1 & 3 & 5 & & Rata-rata \\
\hline $\mathrm{L}_{0}$ & 4,6 & 2,0 & 0,56 & 0,48 & 7,64 & 1,91 \\
$\mathrm{~L}_{1}$ & 4,6 & 3,64 & 2,4 & 2,08 & 12,72 & 3,18 \\
$\mathrm{~L}_{2}$ & 4,64 & 3,72 & 2,72 & 2,44 & 13,52 & 3,38 \\
$\mathrm{~L}_{3}$ & 4,68 & 3,88 & 3,32 & 3,0 & 14,88 & 3,72 \\
\hline Total kelompok & 18,52 & 13,24 & 9 & 8 & 48,76 & \\
\hline
\end{tabular}

Ket: $\mathrm{L}_{0}=0 \%, \mathrm{~L}_{1}=5 \%, \mathrm{~L}_{2}=10 \%, \mathrm{~L}_{3}=15 \%$

\section{Kenampakan Insang}

Hasil uji organoleptic kenampakan insang terlihat bahwa dengan semakin tinggi konsentrasi bubuk rimpang laja gowah yang diberikan maka semakin tinggi juga nilai organoleptic kenampakan insang hal ini disebabkan dengan tingginya konsentrasi yang diberikan sifat antimikroba semakin tinggi, namun semakin lama penyimpanan nilai kenampakan insang ikan gabus semakin 
menurun. Hingga penyimpanan hari ke-5, nilai organoleptic kenampakan insang tertinggi dimiliki oleh $\mathrm{L}_{3}$ yaitu 2,24 sedangkan nilai terendah dimiliki oleh $\mathrm{L}_{0}$ yaitu 0,08 (Tabel 5).

Tabel 5. Nilai organoleptic kenampakan insang ikan gabus yang diawetkan dengan bubuk rimpang laja gowah pada konsentrasi yang berbeda disimpan pada suhu kamar

\begin{tabular}{lllllll}
\hline \multirow{2}{*}{ Perlakuan } & \multicolumn{5}{c}{ Nilai organoleptik } & \\
\cline { 2 - 5 } & \multicolumn{4}{c}{ Lama penyimpanan (hari) } & Total perlakuan & Rata-rata \\
\cline { 2 - 5 } & 0 & 1 & 3 & 5 & & \\
\hline $\mathrm{L}_{0}$ & 4,48 & 2,24 & 1,82 & 0,08 & 8,62 & 2,16 \\
$\mathrm{~L}_{1}$ & 4,52 & 2,68 & 2,64 & 1,04 & 10,88 & 2,72 \\
$\mathrm{~L}_{2}$ & 4,44 & 3,00 & 2,32 & 1,92 & 11,68 & 2,92 \\
$\mathrm{~L}_{3}$ & 4,92 & 3,68 & 3,16 & 2,24 & 14,00 & 3,50 \\
\hline Total kelompok & 18,36 & 11,60 & 9,94 & 5,28 & 45,18 & 11,30 \\
\hline
\end{tabular}

Ket: $\mathrm{L}_{0}=0 \%, \mathrm{~L}_{1}=5 \%, \mathrm{~L}_{2}=10 \%, \mathrm{~L}_{3}=15 \%$

Menurut Hadiwiyoto (1993) warna insang dapat digunakan sebagai tanda apakah ikan masih dalam keadaan segar atau tidak. Pada ikan yang masih segar warna insangnya merah cerah. Sebaliknya ikan yang sudah tidak segar, warna insangnya berubah menjadi coklat gelap. Insang ikan merupakan pusat darah mengambil oksigen dari dalam air. Kematian ikan menyebabkan perananan darah (hemoglobin) berhenti, bahkan sebaliknya darah dapat teroksidasi sehingga warnanya berubah menjadi merah gelap.

\section{Kenampakan mata}

Nilai organoleptic kenampakan mata ikan gabus mengalami penurunan seiring dengan lamanya penyimpanan (Tabel 6). Sampai penyimpanan hari ke-5 nilai tertinggi dimiliki oleh $\mathrm{L}_{3}$ yaitu 3,00 (bola mata agak cekung, pupil putih susu, kornea merah) dan nilai organoleptic terendah adalah $\mathrm{L}_{0}$ sebesar 0,48 (bola mata agak cekung, pupil putih susu, kornea keruh). Hadiwiyoto (1993) menyatakan bahwa parameter keadaan mata merupakan yang paling mudah untuk dilihat. Perubahan kesegaran ikan akan menyebabkan perubahan yang nyata pada kecerahan matanya. Tandatanda ikan segar yaitu mata menonjol ke luar sedangkan ikan tidak segar yaitu mata cekung, masuk ke dalam rongga mata.

Tabel 6. Nilai organoleptic kenampakan mata ikan gabus yang diawetkan dengan bubuk rimpang laja gowah pada konsentrasi yang berbeda disimpan pada suhu kamar

\begin{tabular}{lllllll}
\hline \multirow{2}{*}{ Perlakuan } & \multicolumn{5}{c}{ Nilai organoleptik } & \\
\cline { 2 - 5 } & \multicolumn{4}{c}{ Lama penyimpanan (hari) } & Total perlakuan & Rata-rata \\
\cline { 2 - 5 } & 0 & 1 & 3 & 5 & & \\
\hline $\mathrm{L}_{0}$ & 4,48 & 2,28 & 0,84 & 0,48 & 8,08 & 2,02 \\
$\mathrm{~L}_{1}$ & 4,77 & 2,84 & 2,36 & 2 & 11,97 & 2,99 \\
$\mathrm{~L}_{2}$ & 4,64 & 2,96 & 2,8 & 2,56 & 12,96 & 3,24 \\
$\mathrm{~L}_{3}$ & 4,64 & 3,36 & 3,08 & 3,00 & 14,08 & 3,52 \\
\hline Total kelompok & 18,53 & 11,44 & 9,08 & 8,04 & 47,09 & 11,77 \\
\hline
\end{tabular}

Ket: $\mathrm{L}_{0}=0 \%, \mathrm{~L}_{1}=5 \%, \mathrm{~L}_{2}=10 \%, \mathrm{~L}_{3}=15 \%$

\section{Keadaan lendir}

Hasil uji organoleptic keadaan lendir, terlihat bahwa peningkatan konsentrasi bubuk rimpang laja gowah dapat meningkatkan sifat antimikroba sehingga mengurangi produksi lendir pada ikan (Tabel 7). Namun semakin lama penyimpanan menyebabkan nilai keadaan insang ikan gabus menurun. Nilai organoleptic tertinggi dimiliki oleh $\mathrm{L}_{3}$ yaitu 2,88 sedangkan nilai terendah pada perlakuan $\mathrm{L}_{0}$ sebesar 0,6.
Menurut Hadiwiyoto (1993) timbulnya lendir pada ikan sebagai akibat berlangsungnya proses biokimiawi lebih lanjut dan berkembangnya mikroba.

\section{Tekstur Daging}

Tekstur merupakan salah satu faktor yang mempengaruhi pilihan konsumen terhadap suatu produk pangan. Dari hasil penelitian nilai tekstur daging ikan gabus mengalami penurunan selama penyimpanan, 
sampai penyimpanan hari ke-5 nilai organoleptic tekstur daging ikan gabus tertinggi dimiliki oleh $\mathrm{L}_{3}$ yaitu 3,24 (daging agak lunak, jika ditekan dengan jari belum ada bekasnya) dan nilai terendah pada perlakuan $\mathrm{L}_{0}$ sebesar 0,00 (Tabel 8).

Hadiwiyoto (1993) menyatakan bahwa terjadinya aktimiosin sebagai hasil dari interaksi protein aktin dan myosin dapat menyebabkan daging kehilangan kelenturannya. Selain itu terurainya lipida juga mempunyai andil besar pada perubahan sifat kekerasan daging ikan. Selanjutnya dinyatakan bahwa faktor-faktor yang memegang peranan penting dalam mempertahankan kelenturan ikan adalah perubahan kelarutan protein, kerusakan jaringan daging dan pembebasan asam lemak. Menurut Fardiaz (1992) mikroorganisme mempunyai berbagai enzim yang dapat memecah komponen-komponen yang mengakibatkan perubahan dalam sifat makanan seperti rupa, bau, rasa, dan tekstur.

Tabel 7. Nilai organoleptic keadaan lendir ikan gabus yang diawetkan dengan bubuk rimpang laja gowah pada konsentrasi yang berbeda disimpan pada suhu kamar

\begin{tabular}{lllllll}
\hline \multirow{2}{*}{ Perlakuan } & \multicolumn{4}{c}{ Nilai organoleptik } & & \\
\cline { 2 - 4 } & \multicolumn{4}{c}{ Lama penyimpanan (hari) } & Total perlakuan & Rata-rata \\
\cline { 2 - 4 } & 0 & 1 & 3 & 5 & & \\
\hline $\mathrm{L}_{0}$ & 4,76 & 2,72 & 1,80 & 0,16 & 9,44 & 2,36 \\
$\mathrm{~L}_{1}$ & 4,80 & 3,76 & 2,04 & 2,00 & 12,60 & 3,15 \\
$\mathrm{~L}_{2}$ & 4,84 & 3,92 & 3,04 & 2,08 & 13,88 & 3,47 \\
$\mathrm{~L}_{3}$ & 4,80 & 4,36 & 3,08 & 2,88 & 15,12 & 3,78 \\
\hline Total kelompok & 19,20 & 14,76 & 9,96 & 7,12 & 51,04 & 12,76 \\
\hline
\end{tabular}

Ket: $\mathrm{L}_{0}=0 \%, \mathrm{~L}_{1}=5 \%, \mathrm{~L}_{2}=10 \%, \mathrm{~L}_{3}=15 \%$

Tabel 8. Nilai organoleptic tekstur daging ikan gabus yang diawetkan dengan bubuk rimpang laja gowah pada konsentrasi yang berbeda disimpan pada suhu kamar

\begin{tabular}{|c|c|c|c|c|c|c|}
\hline \multirow{3}{*}{ Perlakuan } & \multicolumn{4}{|c|}{ Nilai organoleptik } & \multirow{3}{*}{ Total perlakuan } & \multirow{3}{*}{ Rata-rata } \\
\hline & \multicolumn{4}{|c|}{ Lama penyimpanan (hari) } & & \\
\hline & 0 & 1 & 3 & 5 & & \\
\hline $\mathrm{L}_{0}$ & 4,64 & 2,56 & 1,16 & 0 & 8,36 & 2,09 \\
\hline $\mathrm{L}_{1}$ & 4,76 & 3,76 & 2,6 & 2,00 & 13,12 & 3,28 \\
\hline $\mathrm{L}_{2}$ & 4,76 & 3,68 & 3,2 & 2,28 & 13,92 & 3,48 \\
\hline $\mathrm{L}_{3}$ & 4,68 & 4,16 & 3,52 & 3,24 & 15,60 & 3,90 \\
\hline Total kelompok & 18,84 & 14,16 & 10,48 & 7,52 & 51,00 & 12,75 \\
\hline
\end{tabular}

Ket: $\mathrm{L}_{0}=0 \%, \mathrm{~L}_{1}=5 \%, \mathrm{~L}_{2}=10 \%, \mathrm{~L}_{3}=15 \%$

\section{Kesimpulan}

\section{KESIMPULAN}

Rimpang laja gowah dapat berfungsi sebagai bahan pengawet terhadap ikan gabus segar. Perlakuan $\mathrm{L}_{3}$ dengan penggunaan bubuk rimpang laja gowah $15 \%$ adalah perlakuan terbaik. Karena mampu mempertahankan mutu ikan gabus sampai 5 hari penyimpanan dilihat dari parameter total bakteri (TPC), nilai TVB dan $\mathrm{pH}$.

\section{Saran}

Berdasarkan hasil penelitian, disarankan menggunakan bubuk rimpang laja gowah $15 \%$ dalam mempertahankan mutu ikan gabus segar selama 5 hari penyimpanan.

\section{DAFTAR PUSTAKA}

Buckle KA, Edwards RA, Fleet G dan Wooton M. 1987. Food Science. Departement of Education and Culture Directorate General of Higher Education. Diterjemahkan oleh Hari Purnomo dan Adiono. Universitas Indonesia. Jakarta. 365 hak.

Connel JJ. 1995. Central of Fish Quality. Carry Research Station Aberden Seetland. Fishing News (Books) Ltd. London. $177 \mathrm{p}$. 
Dinas Perikanan dan Kelautan Provinsi Riau. 2008. Laporan Tahunan Budidaya Ikan Air Tawar. Pekanbaru.

Direktorat Jenderal Pengawasan Obat dan Makanan. 1992. Kumpulan Perundangundangan dibidang makanan dan minuman. Departemen Kesehatan RI. Jakarta. 364 hal.

Fardiaz, S. 1992. Mikrobiologi Pengolahan Pangan. Departemen Pendidikan dan Kebudayaan Direktorat Jendral Pendidikan Tingkat Tinggi Pusat Antar Universitas Pangan dan Gizi. Institut Pertanian Bogor. 215 hal.

Gasperz V. 1994. Metode Perancangan Percobaan. Armico. Bandung. 472 hal.
Hadiwiyoto S. 1993. Teknologi Pengolahan Hasil Perikanan. Jilid I. Liberty. Yogyakarta. 278 hal.

Ilyas. 1993. Teknologi Refrigrasi Hasil Perikanan. Jilid I. Teknik Pendinginan Ikan. Paripurna. Jakarta. 273 hal.

Ilyas. 1997. Teknologi Pasca Panen Hasil Perikanan. Lembaga dan Pengembangan Pertanian. Badan Penelitian dan Pengembangan Pertanian. Departemen Pertanian RI. 190 hal.

Singgih W. 1998. Penanganan Ikan Segar. Diakses pada tanggal 07 November 2008 di:

http://my-curio.us/?p=745 